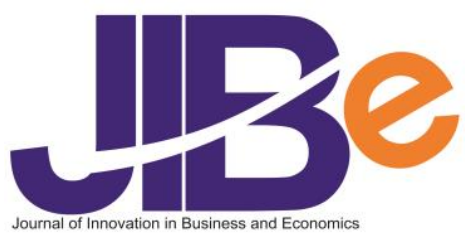

\title{
Analysis of multidimensional poverty dynamics in Indonesia: The effect of demographic and institutional factors
} Esha Najitama $^{1}$, Ghozali Maski ${ }^{2}$, Asfi Manzilati ${ }^{3}$

\author{
Faculty of Economics and Business, Universitas Brawijaya, \\ Indonesia ${ }^{1,2,3}$
}

\begin{abstract}
Measuring poverty only from a monetary perspective is lacking. Given the variety of human needs, poverty needs to be measured multidimensionally. Hence, this study analyzes multidimensional poverty dynamics and identifies its determinants from the demographic and institutional factors. Using the Multidimensional Poverty Index (MPI) and data from the two survey periods of the Indonesia Family Life Survey (IFLS), it is known that multidimensional poverty tends to be transient rather than chronic. The highest education level of the head of the household, the level of dependency, the island of residence, the village political system, and the village government's corruption affect both chronic and transient poverty categories. The marital status of household heads, household size, and customary norms only affected the chronic poor category.
\end{abstract}

Keywords: Poverty dynamics; multidimensional poverty; institutional

\section{Introduction}

Poverty alleviation is an important development goal. However, there is still debate about how poverty should be measured. Poverty is often measured using a monetary approach as a lack of income or consumption from a certain poverty line (Laderchi, Saith, \& Stewart, 2003). However, the monetary approach has been criticized for being too simplistic, uniforming everyone's pattern of consumption, not all needs can be valued in money, and money cannot always be converted into needs (Laderchi et al., 2003; Alkire \& Santos, 2014; Wong, 2012).

One alternative non-monetary poverty measurement developed by Alkire \& Foster (2010) is called the Multidimensional Poverty Index (MPI). Unlike monetary poverty measures that measure poverty indirectly through proxies of income/consumption, MPI measures poverty directly on dimensions that are important to human life, such as health, education, and living standard (Alkire \& Santos, 2014). MPI also refers to the Sustainable Development Goals that target poverty reduction in any form (Alkire, Kanagaratman, \& Suppa, 2018).

Apart from measurement, an important aspect that needs to be considered related to poverty is the duration of time the household experiences poverty. This has led to the concept of poverty dynamics, which separates poor people in the long term or known as chronic poor, from those who are poor for a short time or are called transient poverty. This separation of the poor category is important because it is related to choosing the right policy intervention for each category (Jalan \& Ravallion, 1998; Martinez, Jr., 2016).

Indonesia itself has not adopted the MPI in the official poverty measurement. Research using MPI in Indonesia has been done a lot, although generally, it is static or only uses one year of data. Artha \& Dartanto (2018), for example, only use data for 2011, Sumargo \& Simanjuntak (2019) with data for 2014, and Salam, Pratomo, \& Saputra (2020) with data for 2018. When using several years of data, multidimensional poverty analysis is still descriptive or trend in nature, as done by Wardhana (2010), Sumarto, Sudarno, \& Indunil (2014), and Hanandita \& Tampubolon (2016). These studies have not shown the existence of a chronic or transient multidimensional poverty phenomenon.

Therefore, this study specifically wants to complement the previous research by dynamically analyzing multidimensional poverty using data from several years or panel data so that the persistence of a household's poverty from year to year can be seen. This study looks at the determinants of the dynamics of poverty from demographic and institutional factors that represent internal and external household conditions as well as individual and structural factors of poverty. Demographic factors are frequently studied factors related to poverty, while institutional factors at the village level have not been studied much so that they contribute to research in this field. This institutional factor also needs to be examined

\footnotetext{
${ }^{1}$ E-mail: esha.najitama@gmail.com
} 
considering that Indonesia is currently increasingly decentralized, and the role of villages is increasingly important, among others, in poverty alleviation efforts.

This study shows that multidimensional poverty in Indonesia is more transient than chronic. Transient poor households tend to be deprived in the health dimension, while chronic poor households are deprived in the dimension of living standards. Demographic and institutional factors such as the highest education level of the head of the household, the level of dependence, the island of residence, the village political system, and the village government's corruption have a significant effect on both chronic and transient poverty. The marital status of household heads, household size, and customary norms only affect chronic multidimensional poverty.

\section{Literature Review \\ Multidimensional Poverty Index}

Poverty is a multidimensional social phenomenon (Narayan, Patel, Schafft, Rademacher, \& Schulte, 1999). Poverty is not only in the form of lack of money, but deprived living conditions, poor health, lack of education, even including the absence of freedom (Kim, 2019; Narayan et al., 1999). However, the measurement of poverty is still dominated by using only one dimension, namely monetary (Laderchi et al., 2003). One of the efforts to measure poverty that considers many dimensions was developed by Alkire \& Foster (2010), called the Multidimensional Poverty Index (MPI). This MPI is an effort to operationalize the capability approach developed by Amartya Sen (Ivanov \& Kagin, 2014).

MPI measures poverty directly on whether the dimensions important to welfare are owned by a household (Alkire \& Santos, 2014). MPI provides flexibility for each country to determine its own dimensions and poverty indicators as a National MPI (Alkire \& Foster, 2011). In the context of comparisons between countries, UNDP and the Oxford Poverty and Human Development Initiative (OPHI) created a Global MPI consisting of three main dimensions: education, health, and living standards (Alkire et al., 2018). The three dimensions are then described in 10 indicators compiled refer to the Sustainable Development Goals (SDGs). Although there are many criticisms, especially related to weighting and the exchange of calculations between index components (Bautista, 2018), MPI has the advantage of being easy to implement and interpret. Also, the MPI results can be decomposed to see further the characteristics of multidimensional poverty (Alkire \& Foster, 2010).

\section{Dynamics of Poverty}

The dynamics of poverty is a concept of poverty that is related to time (Foster, 2007). This concept departs from the view that residents' or households' poverty conditions are not static (fixed) but dynamic (changing) from time to time. With the measurement in a long time, it will be seen how the level of poverty persistence experienced by a household can be distinguished between households that are poor in a long time (chronic poor) and poor in a short time (transient poor) (Hulme \& Shepherd, 2003).

In general, there are two methods to distinguish chronic and transient poverty categories, namely the component and spells approach (Foster, 2007). The component approach uses the longitudinal average income to determine whether a household is chronically poor or not. The spells approach calculates the number of poverty episodes experienced by a household (Martinez, Jr., 2016). This research uses the spells approach previously applied to multidimensional poverty, as was done by Mauricio, Apablaza. Yalonetzky (2012), Alkire, Apablaza, Chakravarty, \& Yalonetzky (2017), and Adepoju (2018).

\section{Determinants of Poverty}

Poverty theories distinguish the main causes of poverty from two major perspectives: an individualistic perspective that places the causes of poverty on individual deficiency and a structural perspective that places the causes of poverty in a broader social phenomenon (Bradshaw, 2007; Royce, 2018). Individual perspective poverty theory views the causes of poverty in the conditions or individual attributes of the poor themselves, often referred to as micro-level characteristics (Calnitsky, 2018). On the other hand, the structural poverty theory sees poverty as a social problem associated with various economic, political, cultural, and social forces beyond the individual's direct control (Royce, 2018).

Although not using a dynamic concept, previous research on multidimensional poverty has looked at the factors that cause poverty, including the age of the household head, the household head's marital status, the highest education of household head, household size, level of dependency, and location (Adeoti, 2014; Adepoju, 2018; Alkire \& Fang, 2019; Artha \& Dartanto, 2018; Bautista, 2018; Salam et al., 2020; Tran, Alkire, \& Klasen, 2015). For institution factors such as the political system and corruption, Asongu \& Kodila-Tedika (2018) have studied the relationship with poverty, although at the level between countries. 


\section{Research Method}

This study uses data from the Indonesia Family Life Survey (IFLS) for two periods, is IFLS-4 (2007/2008) and IFLS-5 (2014/2015). Because this research is dynamic by considering community or village factors, only the household respondents surveyed in the two IFLS periods and still live in the IFLS sample community can be used in this study, that is 7,296 households. The general description of respondents based on household characteristics in the IFLS-4 period can be seen in Table 1 .

\section{Multidimensional Poverty Measurement}

Considering that Indonesia has not formally established multidimensional poverty indicators, this study refers to the dimensions and indicators in the Global MPI with several adjustments, as can be seen in Table 2. Following the Global MPI, the multidimensional poverty line used is 0.33 .

Table 1. General Description of Research Respondents

\begin{tabular}{|c|c|c|c|c|c|c|c|}
\hline No & Variable & Category & Amount & Percent & Min & Max & Mean \\
\hline 1. & Age of household head & & & & 13 & 100 & 47,5 \\
\hline 2. & $\begin{array}{l}\text { The marital status of the } \\
\text { head of the household }\end{array}$ & $\begin{array}{l}\text { Married } \\
\text { Not married }\end{array}$ & $\begin{array}{l}6.014 \\
1.282\end{array}$ & $\begin{array}{l}82,4 \% \\
17,6 \%\end{array}$ & & & \\
\hline 3. & $\begin{array}{l}\text { The highest education of the } \\
\text { head of the household }\end{array}$ & $\begin{array}{l}\text { Primary school and } \\
\text { below } \\
\text { Junior high school } \\
\text { Senior high school } \\
\text { Higher education }\end{array}$ & $\begin{array}{r}4.391 \\
1.064 \\
1.365 \\
476\end{array}$ & $\begin{array}{r}60,2 \% \\
14,6 \% \\
18,7 \% \\
6,5 \%\end{array}$ & & & \\
\hline 4. & Household size & & & & 1 & 14 & 4,04 \\
\hline 5. & Dependency level & & & & 0 & 1 & 0,34 \\
\hline 6. & Residential island & $\begin{array}{l}\text { Jawa-Bali } \\
\text { Outside Jawa-Bali }\end{array}$ & $\begin{array}{l}4.607 \\
2.689\end{array}$ & $\begin{array}{l}63,1 \% \\
36,9 \%\end{array}$ & & & \\
\hline 7. & Village political system & $\begin{array}{l}\text { Democracy } \\
\text { Others }\end{array}$ & $\begin{array}{l}5.438 \\
1.858\end{array}$ & $\begin{array}{l}74,5 \% \\
25,5 \%\end{array}$ & & & \\
\hline 8. & Customary norms & $\begin{array}{l}\text { Strong } \\
\text { Others }\end{array}$ & $\begin{array}{l}1.855 \\
5.441\end{array}$ & $\begin{array}{l}25,4 \% \\
74,6 \%\end{array}$ & & & \\
\hline 9. & $\begin{array}{l}\text { Village government } \\
\text { corruption }\end{array}$ & $\begin{array}{l}\text { High } \\
\text { Others }\end{array}$ & $\begin{array}{r}374 \\
6.922 \\
\end{array}$ & $\begin{array}{r}5,1 \% \\
94,9 \% \\
\end{array}$ & & & \\
\hline
\end{tabular}

Table 2. Dimensions and Multidimensional Poverty Indicators

\begin{tabular}{|c|c|c|c|c|}
\hline No & Dimentions & Indicator & The household is deprived if ... & Weight \\
\hline \multirow[t]{2}{*}{1.} & \multirow[t]{2}{*}{ Health } & Nutrition & $\begin{array}{l}\text { There are family members under } 70 \text { who are malnourished. } \\
\text { For adults (age } \geq 20 \text { years) have a Body Mass Index (BMI) } \\
<18.5 \text {; ages between } 5-19 \text { years have an age-appropriate } \\
\text { BMI < WHO standard. For toddlers (aged } \leq 5 \text { years) have a } \\
\text { Z-score }>-2 \text { Standard Deviation (SD) }\end{array}$ & $1 / 6$ \\
\hline & & $\begin{array}{l}\text { Child } \\
\text { mortality }\end{array}$ & $\begin{array}{l}\text { Any child (under } 18 \text { years) has died in the family in the five } \\
\text { year preceding the survey. }\end{array}$ & $1 / 6$ \\
\hline \multirow{2}{*}{2.} & \multirow{2}{*}{ Education } & $\begin{array}{l}\text { Years of } \\
\text { schooling }\end{array}$ & $\begin{array}{l}\text { No household member has completed six years of schooling } \\
\text { (primary school). }\end{array}$ & $1 / 6$ \\
\hline & & $\begin{array}{l}\text { School } \\
\text { attendance }\end{array}$ & Any school-aged child ( $7-15$ years) is not attending school. & $1 / 6$ \\
\hline \multirow{6}{*}{3.} & \multirow{6}{*}{$\begin{array}{l}\text { Living } \\
\text { Standards }\end{array}$} & Cooking fuel & The household cooks with dung, wood or charcoal. & $1 / 18$ \\
\hline & & Sanitation & $\begin{array}{l}\text { The household does not have a proper sanitation facility or } \\
\text { is shared with other households. }\end{array}$ & $1 / 18$ \\
\hline & & $\begin{array}{l}\text { Drinking } \\
\text { water }\end{array}$ & $\begin{array}{l}\text { The household does not have access to proper drinking } \\
\text { water, such as water sources from wells/unprotected } \\
\text { springs/rivers/rainwater/ponds. }\end{array}$ & $1 / 18$ \\
\hline & & Electricity & The household has no electricity. & $1 / 18$ \\
\hline & & Housing & $\begin{array}{l}\text { The household has inadequate housing: the floor, wall, or } \\
\text { roof is of natural or rudimentary materials. }\end{array}$ & $1 / 18$ \\
\hline & & Assets & $\begin{array}{l}\text { The household does not own these assets: radio, TV, } \\
\text { telephone, bicycle, motorbike, refrigerator, and does not } \\
\text { own a car or truck. }\end{array}$ & $1 / 18$ \\
\hline
\end{tabular}


Multidimensional Poverty Determinants Model

The model used in this study is multinomial logistic regression as used by Adepoju (2018), Alisjahbana \& Yusuf (2003), and Astuti, Asra, \& Ilmma (2012). The dependent variable categories are Y $=1 ;$ chronic multidimensional poor; $\mathrm{Y}=2$; transient multidimensional poor; $\mathrm{Y}=3$; never multidimensional poor.

The multidimensional dynamic model of poverty is as follows equation (1).

$\ln \left(\frac{P_{i}}{P_{3}}\right)=\mathrm{z}_{\mathrm{i}}=\beta_{\mathrm{i} 1}+\beta_{\mathrm{i} 2}$ AGE $+\beta_{\mathrm{i} 3}$ AGE $2+\beta_{\mathrm{i} 4}$ STATUS $+\beta_{\mathrm{i} 5}$ EDUCATION $+\beta_{\mathrm{i} 6}$ SIZE $+\beta_{\mathrm{i} 7}$ DEPENDENT

$+\beta_{\mathrm{i} 8}$ ISLAND $+\beta_{\mathrm{i} 9}$ POLITIC $+\beta_{\mathrm{i} 10}$ NORMS $+\beta_{\mathrm{i} 11}$ CORRUPTION $+\varepsilon \mathrm{i}, \mathrm{i}=1,2$

The comparison category used is $\mathrm{Y}=3$ (never poor). The independent variables and their operational definitions are as follows.

1. Age of household head (AGE) and quadratic age of household head (AGE2) are the numbers of years of household life. KRT age squared is the sum of household head age squares. These two variables are calculated numerically.

2. The marital status of the household head (STATUS) is the marital status of the household head, which is categorized into two, namely $1=$ married (paired) and $0=$ unmarried (unmarried or divorced life/death).

3. The highest education level for KRT (EDUCATION) is the highest education level of KRT, which is calculated ordinal where the value is $1=\mathrm{SD}$ and below; $2=\mathrm{SMP} ; 3=\mathrm{SMA}$; and $4=$ higher education (D1 and above).

4. Household size (SIZE) is the number of household members living and living together in the household. The household size is calculated numerically.

5. Dependency level (DEPENDENT) is the ratio between the number of household members who are not in the workforce (aged 0-14 years \& ages 65 and over) with the total number of household members. The dependency measure is calculated in numerical form.

6. Residential island (ISLAND) is an island where households live, divided into two categories, namely 1 $=$ Java-Bali Island and $0=$ outside Java-Bali Island.

7. Village political system (POLITIC) is a village head election system categorized into two, namely $1=$ Democracy and $0=$ No Democracy.

8. Customary norms (NORMS) are perceptions of customary rules' strength in influencing citizens' lifestyles, divided into two categories, namely $1=$ Strong and $0=$ Others.

9. Village government corruption (CORRUPTION) is the perception of corruption cases, collusion, and nepotism in village government, divided into two, namely $1=$ High, and $0=$ Others.

\section{Result and Discussion}

\section{Number and Contributors of Multidimensional Poverty}

The calculation of the multidimensional poverty status of the respondent households shows that the number of multidimensional poor households dynamically can be seen in Figure 1. Figure 1 shows the movement of household poverty status were from $13.2 \%$ of poor households in IFLS-4, 3.2\% remained poor, and as many as $9.9 \%$ managed to get out of poverty in IFLS-5. Some households were also not poor in IFLS-4, which turned out to be poor in the IFLS-5 period, namely as much as $3.2 \%$. Therefore, dynamically, the multidimensional poverty rate of households in Indonesia is $16.3 \%$, consisting of $3.2 \%$ of the status of chronic poor and $13.1 \%$ of the transient poor. This figure shows that multidimensional poverty is more likely to be transient than chronic.

One of the MPI advantages is that it can be decomposed to see each dimension's contribution or indicator to poverty. The decomposition of chronic and transient poverty on average between the IFLS-4 and IFLS-5 periods can be seen in Figure 2. 


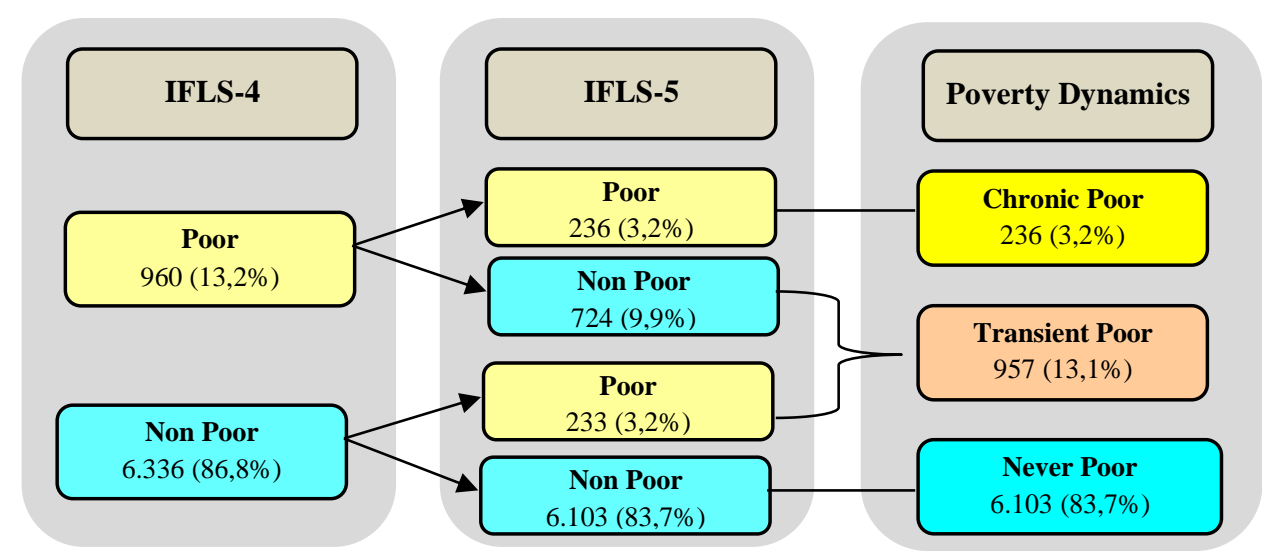

Source: IFLS-4 (2007) and IFLS-5 (2014), processed.

Figure 1. The Dynamics of Multidimensional Poverty

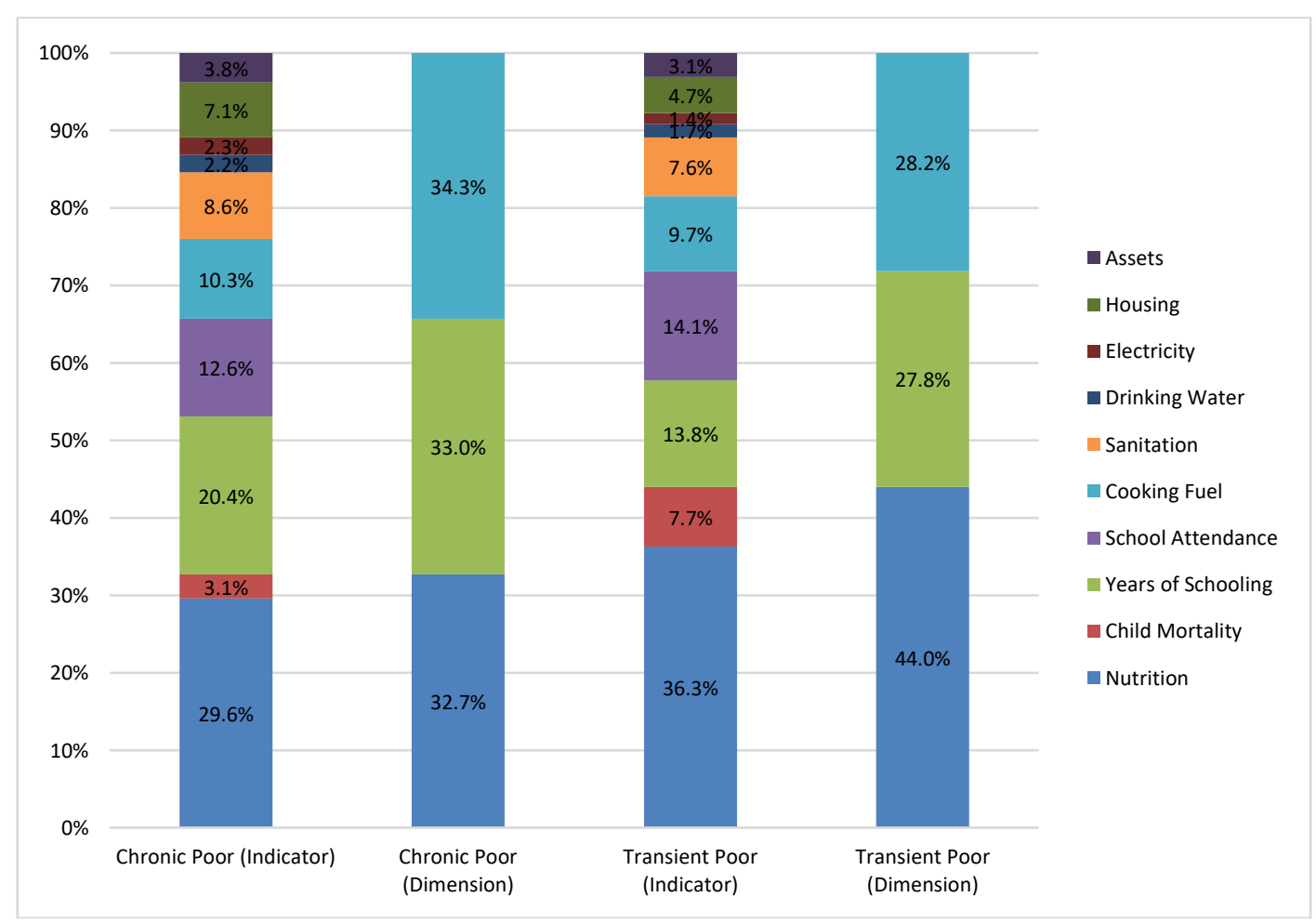

Source: IFLS-4 (2007) dan IFLS-5 (2014), processed.

Figure 2. Contribution of Multidimensional Poverty Dynamics

Figure 2 shows that chronic poverty is mostly contributed by the dimension of living standards $(34.3 \%)$, which is relatively difficult to change, while transient poverty is dominated by the health dimension (44.0\%). Looking at the indicators, nutrition, years of schooling, school attendance, cooking fuel, and sanitation are the main contributors to the two poverty categories.

When compared, it appears that chronic poverty tends to be greater in indicators of years of schooling, sanitation, electricity, housing, and asset. Meanwhile, transient poverty was greater in indicators of nutrition, child mortality, and school attendance. The indicators with the same portion in the two poverty categories are cooking fuel and drinking water. This shows that the poor's problems vary, especially by households whose chronically poor and transient poor. 
The Determinants of Multidimensional Poverty Dynamics

The multinomial logistic regression results on the determinants of multidimensional poverty can be seen in table 3 .

Table 3. Estimation Results of Multidimensional Poverty Dynamics

\begin{tabular}{|c|c|c|c|c|c|c|c|c|}
\hline \multirow{3}{*}{$\begin{array}{c}\mathbf{N} \\
\mathbf{o}\end{array}$} & \multirow{3}{*}{ Variable } & \multicolumn{4}{|c|}{ Multidimensional Poverty Dynamics } & \multicolumn{3}{|c|}{ Marginal Effect } \\
\hline & & \multicolumn{2}{|c|}{ Chronic poor } & \multicolumn{2}{|c|}{ Transient Poor } & \multirow{2}{*}{$\begin{array}{l}\text { Chronic } \\
\text { Poor }\end{array}$} & \multirow{2}{*}{$\begin{array}{l}\text { Transient } \\
\text { Poor }\end{array}$} & \multirow{2}{*}{$\begin{array}{c}\text { Never } \\
\text { Poor }\end{array}$} \\
\hline & & coeff. & pvalue & coeff. & pvalue & & & \\
\hline \multirow[t]{2}{*}{1.} & Age of household head & .0455 & 0.162 & -.0195 & 0.233 & .00148 & -.00238 & .0008 \\
\hline & - Age squared & -.0004 & 0.142 & .00016 & 0.315 & -.00001 & .00002 & $-5.29 \mathrm{e}-$ \\
\hline 2. & $\begin{array}{l}\text { Marital status of the } \\
\text { head of the household }\end{array}$ & -.4980 & $0.002 * * *$ & -.0046 & 0.963 & $.0148 * * *$ & .00273 & .01212 \\
\hline 3. & $\begin{array}{l}\text { Highest education of the } \\
\text { head of the household }\end{array}$ & -1.562 & $0.000 * * *$ & -.8915 & $\begin{array}{r}0.000 * * \\
*\end{array}$ & $.0409 * * *$ & $-.0851 * * *$ & $.1261 * * *$ \\
\hline 4. & Household size & -.2288 & $0.000 * * *$ & .00796 & 0.715 & $.0068 * * *$ & .00233 & $.0045^{*}$ \\
\hline 5. & Dependency level & 1.157 & $0.000 * * *$ & 1.063 & $\begin{array}{r}0.000 * * \\
*\end{array}$ & $.0277 * * *$ & $.1061 * * *$ & $-.1339 * * *$ \\
\hline 6. & Residential island & -.6181 & $0.000 * * *$ & -.4521 & $\begin{array}{r}0.000 * * \\
*\end{array}$ & $.0155 * * *$ & $-.0443 * * *$ & $.0598 * * *$ \\
\hline 7. & Village political system & 1.442 & $0.000 * * *$ & .69175 & $\begin{array}{r}0.000 * * \\
*\end{array}$ & $.0386 * * *$ & $.0646 * * *$ & $-.1032 * * *$ \\
\hline 8. & Customary norms & -.4657 & $0.006 * * *$ & -.1181 & 0.157 & $.0131 * * *$ & -.00961 & $.02277 * *$ \\
\hline 9. & $\begin{array}{l}\text { Village government } \\
\text { corruption }\end{array}$ & 1.053 & $0.000 * * *$ & .60021 & $\begin{array}{r}0.000 * * \\
*\end{array}$ & $.0276 * * *$ & $.0573 * * *$ & $-.0849 * * *$ \\
\hline
\end{tabular}

Source: Analysis results of IFLS-4 (2007) and IFLS-5 (2014).

Information: Dependent variable: status of poverty dynamics $(1=$ chronic poor; $2=$ transient poor; $3=$ never poor $)$, with basic

category 3 (never poor). *** significant at $\alpha=1 \%$, ** significant at $\alpha=5 \%$, * significant at $\alpha=10 \%$.

Table 3 shows that except age and age squared of the household head, demographic and institutional factors influence the dynamics of multidimensional poverty. The highest education of the head of the household, dependency level, residential island, village political system, and village government corruption affect both chronic and transient poverty categories. The head of the household's marital status, household size, and customary norms only affect the chronic poor category.

The age and age squared of the household heads do not significantly affect the dynamics of multidimensional poverty. Although increasing age is often associated with high productivity and income in monetary terms (Astuti et al., 2012), the increase in income does not always raise welfare non-monetary. This is due to the different ways of converting income between households in fulfilling their daily needs. For example, Banerjee (2008) revealed that additional money does not always turn into extra nutrition in families experiencing malnutrition. The increase in household members' number as the household head grows older also increases the risk of problems in the non-monetary dimension, such as malnutrition and children's education. This study's results are similar to Adepoju (2018), which shows that the household head's age does not affect multidimensional poverty, both chronic and transient. However, this study's results are different from Alkire \& Fang (2019) which state that multidimensional poverty decreases with increasing age until the effect is reversed at a certain point.

Households with the married or paired head of household had a lower chance of being chronic multidimensional poor by $1.48 \%$ than households with the unpaired household head. This is partly because the couple can help the household head both by working and taking care of the household so that the household's welfare condition is better (Yusrina, 2013). However, households with partners tend to be large so that other challenges arise, such as nutrition and children's schooling, so that the transient poor category's effect is not visible. This study's results are similar to Alkire \& Fang (2019) and Adepoju (2018), which reveal that married domestic workers have a lower likelihood of becoming multidimensional poor. However, this study's results are different from Artha \& Dartanto (2018), which shows that married heads of families are more likely to be poor.

The highest education level of the head of household is proven to influence the dynamics of multidimensional poverty significantly. Improving household education will reduce the chances of households becoming chronically and transient poor by $4.1 \%$ and $8.5 \%$, respectively, and increasing the chances of never being poor by $12.6 \%$. As human capital, education is a significant investment to get out of poverty. An educated household head will be better prepared to face risks and uncertainties (Adepoju, 2018), be better at converting the income it earns, care more about children's education, pay attention to 
health, and care about a decent standard of living, thereby reducing the multidimensional opportunities for poverty. This study's results support the findings of Alkire \& Fang (2019), Tran et al. (2015), Bautista (2018), Adepoju (2018), Adeoti (2014), Artha \& Dartanto (2018), and Salam et al. (2020).

Household size has a significant influence on multidimensional poverty dynamics. Interestingly, this influence has a negative direction, indicating that an increase in household members' number reduces the chance of a chronic multidimensional poor household by $0.7 \%$. This result is partly because additional household members can become household investments; for example, some additional children can go to school higher than their parents. The results support Adepoju (2018), which links the addition of household members with an increase in additional labor, which increases productivity so that it can be used to overcome the multidimensional dimensions of poverty. These results are similar to those of Tran et al. (2015) that additional ART can reduce multidimensional poverty even when more than six opportunities increase. This result is different from Artha \& Dartanto (2018) and Adeoti (2014), where the greater the chance of being poor.

The dependency levels have a positive effect on increasing the chances of households becoming multidimensional poor. An increase in the level of dependence increased the chances of a household becoming chronically and transient poor by $2.8 \%$ and $10.6 \%$, respectively, and reduced the chance of not being poor by $13.4 \%$. This result shows the importance of a household structure where when the household consists of many household members of unproductive age (children and the elderly), the household's burden is getting heavier, which increases the tendency to become poor. This study's results are similar to those of Salam et al. (2020), which links the additional unproductive ART as an additional burden that requires the fulfillment of proper health nutrition.

Households living on the island of Java-Bali are less likely to be chronic and transient multidimensional poverty by $1.6 \%$ and $4.4 \%$, respectively, and increase the chance of not being poor multidimensional by $5.9 \%$ compared to living outside the island Java-Bali. This shows the inequality of access to welfare, be it health, education, or a decent standard of living between the islands of Java-Bali and outside Java-Bali. This study supports Kusuma \& Muta'ali (2019) regarding infrastructure inequality, which causes the opportunities for households living outside the island of Java-Bali to be multidimensional poor.

The village political system shows a significant influence on the dynamics of multidimensional poverty. Interestingly, living in a democratic community increases the chances of a chronically and poor transient household by $3.9 \%$ and $6.5 \%$, respectively, and reduces the chance of never being poor by $10.3 \%$. Democracy as a political system does not automatically create equitable welfare (UNRISD, 2010). The high cost of politics, such as the practice of buying and selling votes (vote-buying), results in only the village elite who can compete to become village leaders (Aspinall \& Rohman, 2017) and tend to require a return on capital when elected. Also, Indonesia's democratic system tends to be implemented in rural areas, which in terms of budget and facilities are more behind compared to cities.

Customary norms show a significant influence on the dynamics of chronic multidimensional poverty. Households living in communities with strong customary norms reduce their chances of being chronically poor by $1.3 \%$ and increase their chances of never being poor by $2.3 \%$. The results of this study indicate that customary norms can help households overcome poverty. This is possible because customary norms are part of social capital that binds its members to create interaction and cooperation. This cooperation bond can be a solution when a household experiences difficulties (Islam \& Alam, 2018; Fukuyama, 2001). This study supports the findings of Yamin \& Dartanto (2016) that social capital plays a vital role in overcoming poverty.

Village government corruption shows a negative influence on the dynamics of multidimensional poverty. Households living in a community with a corrupt village government increased their chances of being poor, both chronic and transient, by $2.8 \%$ and $5.7 \%$, respectively, and decreased the chance of not being poor multidimensional by $8.5 \%$. The results of this study support the findings of Gupta, Davoodi, \& Alonso-Terme (2002) and Samputra \& Munandar (2019), which show that corruption has a positive relationship with poverty, among others through decreased income, distorting the composition of spending, unfair distribution of resources and services, and reduce service quality. This study also supports Olken (2006) that the cost of corruption in Indonesia is enormous and hinders the government's ability to redistribute, especially in rural areas.

\section{Conclusions, suggestions and limitations}

This study aims to analyze multidimensional poverty dynamics, including its determinants from demographic and institutional factors. The results showed that poverty in Indonesia is more likely to be transient than chronic. Although most of the affecting indicators are the same, chronically poor households 
are more likely to be deprived in the dimension of living standards, while transient poor households are deprived in the health dimension.

Apart from age and age squared of household heads, which do not significantly affect, demographic and institutional factors significantly affect multidimensional poverty dynamics. The highest education level of the head of the household, the level of dependency, the island of residence, the village political system, and the village government's corruption affect both chronic and transient poverty categories. The head of the household's marital status, household size, and customary norms only affect the chronic poor category. These three variables can be used to differentiate between households that tend to be chronically poor compared to transient poor. Households that tend to be chronically poor are households with unmarried (unpaired) heads of households with a small number of household members so that internally they lack mutual support. Also, these households live in an environment with weak customary norms, which indicates that they lack access to assistance from others.

This study suggests the government complement the existing monetary poverty measures with multidimensional measures so that the focus of poverty reduction is not only on monetary aspects such as increasing consumption but also on other dimensions that are directly important in human life. Households with a married head of household show better welfare, so that the government needs to encourage people to get married and not live alone so that someone can help improve multidimensional welfare. The government also needs to increase human capital (education/training) for poor households, support access to essential services, especially for poor households with a small number of household members, poor households with high dependency structures (many children /elderly), and living in areas outside the island of Java-Bali.

Also, poverty alleviation needs to be supported by improvements in institutional aspects at the village level. The democratic system needs to be simplified to reduce political costs and increase social capital as a role for society in overcoming poverty. The implementation of good governance through transparency and accountability also needs to be improved to ensure that corruption does not occur and the policies taken by the village government are pro-poor (pro-poor policy).

This study has the limitation that it only uses two survey periods in looking at the dynamics of poverty. The institutional proxies used are mostly perception, with a limited number of respondents representing the community. The use of more extended research periods and more representative institutional measures can enrich research in this area.

\section{Acknowledgement}

The author would like to thank Pusbindiklatren Bappenas, who has provided funding, and the Audit Board of the Republic of Indonesia, who has given permission to study at Brawijaya University and conducting this research.

\section{References}

Adeoti, A. I. (2014). Trend and Determinants of Multidimensional Poverty in Rural Nigeria. Journal of Development and Agricultural Economics, 6(5), 220-231. https://doi.org/10.5897/jdae2013.0535

Adepoju, A. (2018). Determinants of Multidimensional Poverty Transitions Among Rural Households in Nigeria. International Conference of Agricultural Economists.

Alisjahbana, A., \& Yusuf, A. A. (2003). Poverty Dynamics In Indonesia : Panel Data Evidence. Working Paper in Center for Economics and Development Studies, Padjadjaran University, (6).

Alkire, S., Apablaza, M., Chakravarty, S., \& Yalonetzky, G. (2017). Measuring Chronic Multidimensional Poverty. Journal of Policy Modeling, 39(6), 983-1006. https://doi.org/10.1016/j.jpolmod.2017.05.020

Alkire, S., \& Fang, Y. (2019). Dynamics of Multidimensional Poverty and Uni-dimensional Income Poverty: An Evidence of Stability Analysis from China. Social Indicators Research, 142(1), 2564. https://doi.org/10.1007/s11205-018-1895-2

Alkire, S., \& Foster, J. (2010). Counting and Multidimensional Poverty Measurement. Journal of Public Economics, 95(7-8), 476-487. https://doi.org/10.1016/j.jpubeco.2010.11.006

Alkire, S., \& Foster, J. (2011). Understandings and Misunderstandings of Multidimensional Poverty Measurement. Journal of Economic Inequality, 9(2), 289-314. https://doi.org/10.1007/s10888011-9181-4

Alkire, S., Kanagaratman, U., \& Suppa, N. (2018). The Global Multidimensional Poverty Index (MPI): 2018 Revision. In OPHI MPI Methodological Notes 46 (Vol. 31). Retrieved from http://hdr.undp.org/en/2018-MPI 
Alkire, S., \& Santos, M. E. (2014). Measuring Acute Poverty in the Developing World: Robustness and Scope of the Multidimensional Poverty Index. World Development, 59, 251-274. https://doi.org/10.1016/j.worlddev.2014.01.026

Artha, D. R. P., \& Dartanto, T. (2018). The multidimensional approach to poverty measurement in Indonesia: Measurements, determinants and its policy implications. Journal of Economic Cooperation and Development, 39(3), 1-38.

Asongu, S. A., \& Kodila-Tedika, O. (2018). Institutions and Poverty: A Critical Comment Based on Evolving Currents and Debates. Social Indicators Research, 139(1), 99-117. https://doi.org/10.1007/s11205-017-1709-y

Aspinall, E., \& Rohman, N. (2017). Village Head Elections in Java: Money Politics and Brokerage in the Remaking of Indonesia's Rural Elite. Journal of Southeast Asian Studies, 48(1), 31-52. https://doi.org/10.1017/S0022463416000461

Astuti, A. N., Asra, A., \& Ilmma, A. (2012). Poverty Dynamics in Indonesia, 2008-2010 (pp. 15-35). pp. 15-35. Review of Indonesian Economic and Business Studies.

Banerjee, A. V. (2008). Why Fighting Poverty is Hard. In Frontiers of Knowledge (pp. 347-359). Madrid.

Bautista, C. C. (2018). Explaining Multidimensional Poverty: A Household-Level Analysis. Asian Economic Papers, 13(3), 30-58. https://doi.org/10.1162/ASEP

Bradshaw, T. K. (2007). Theories of Poverty and Anti-Poverty Programs in Community Development. Community Development, 38(1), 7-25. https://doi.org/10.1080/15575330709490182

Calnitsky, D. (2018). Structural and Individualistic Theories of Poverty. Sociology Compass, 12(12), 1-14. https://doi.org/10.1111/soc4.12640

Foster, J. E. (2007). A Class of Chronic Poverty Measures. Manchester, UK.

Fukuyama, F. (2001). Social Capital, Civil Society and Development. Third World Quarterly, 22(1), 7-20. https://doi.org/10.1080/713701144

Gupta, S., Davoodi, H., \& Alonso-Terme, R. (2002). Does Corruption Affect Income Inequality and Poverty? Economics of Govrnance, 3, 23-45.

Hanandita, W., \& Tampubolon, G. (2016). Multidimensional Poverty in Indonesia: Trend Over the Last Decade (2003-2013). Social Indicators Research, 128(2), 559-587. https://doi.org/10.1007/s11205-015-1044-0

Hulme, D., \& Shepherd, A. (2003). Conceptualizing Chronic Poverty. World Development, 31(3), 403423. https://doi.org/10.1016/S0305-750X(02)00222-X

Islam, M. S., \& Alam, K. (2018). Does Social Capital Reduce Poverty? A Cross-Sectional Study of Rural Household in Bangladesh. International Journal of Social Economics, 45(11), 1515-1532. https://doi.org/10.1108/IJSE-07-2017-0295

Ivanov, A., \& Kagin, J. (2014). Roma Poverty from A Human Development Perspective. Istambul.

Jalan, J., \& Ravallion, M. (1998). Determinants of Transient and Chronic Poverty: Evidence from Rural China. In Policy Research Working Paper. https://doi.org/10.1596/1813-9450-1936

Kim, H. (2019). Beyond Monetary Poverty Analysis: The Dynamics of Multidimensional Child Poverty in Developing Countries. Social Indicators Research, 141(3), 1107-1136. https://doi.org/10.1007/s11205-018-1878-3

Kusuma, M. E., \& Muta'ali, L. (2019). Hubungan Pembangunan Infrastruktur dan Perkembangan Ekonomi Wilayah Indonesia. Jurnal Bumi Indonesia, 8(3).

Laderchi, C. R., Saith, R., \& Stewart, F. (2003). Does It Matter that We Do Not Agree on the Definition of Poverty? A Comparison of Four Approaches. Oxford Development Studies, 31(3), 243-274. https://doi.org/10.1080/1360081032000111698

Martinez, Jr., A. (2016). Analytical Tools for Measuring Poverty Dynamics: An Application Using Panel Data in the Philippines. In $A D B$ Economics Working Paper Series Analytical. https://doi.org/10.2139/ssrn.2811521

Mauricio, Apablaza. Yalonetzky, G. (2012). Chronic Multidimensional Poverty or Multidimensional Chronic Deprivation. OPHI Research in Progress Series 2012.

Narayan, D., Patel, R., Schafft, K., Rademacher, A., \& Schulte, S. K. (1999). Can Anyone Hear Us? Voice from 47 Countries.

Olken, B. A. (2006). Corruption and the Costs of Redistribution: Micro Evidence from Indonesia. Journal of Public Economics, 90(4-5), 853-870. https://doi.org/10.1016/j.jpubeco.2005.05.004

Royce, E. (2018). Poverty and Power: The Problem of Structural Inequality (Third Edit). United States: The Rowman \& Littlefield Publishing Group, Inc. 
Salam, A., Pratomo, D. S., \& Saputra, P. M. A. (2020). Sosio-economic determinants of multidimensional poverty in the rural and urban areas of East Java. International Journal of Scientific and Technology Research, 9(4), 1445-1449.

Samputra, P. L., \& Munandar, A. I. (2019). Korupsi, Indikator Makro Ekonomi, dan IPM terhadap Tingkat Kemiskinan di Indonesia. Jurnal Ekonomi Kuantitatif Terapan, 12(1), 35-46. https://doi.org/10.24843/jekt.2019.v12.i01.p04

Sumargo, B., \& Simanjuntak, N. M. M. (2019). Deprivasi Utama Kemiskinan Multidimensi Antarprovinsi di Indonesia. Jurnal Ekonomi Dan Pembangunan Indonesia, 19(2), 160-172. https://doi.org/10.21002/jepi.v19i2.793

Sumarto, S., Sudarno, S., \& Indunil, de S. (2014). Beyond the Headcount: Examining the Dynamics and Patterns of Multidimensional Poverty in Indonesia. Working Paper, (December).

Tran, V. Q., Alkire, S., \& Klasen, S. (2015). Static and Dynamic Disparities Between Monetary and Multidimensional Poverty Measurement: Evidence from Vietnam. Measurement of Poverty, Deprivation, and Economic Mobility.

Wardhana, D. (2010). Multidimensional Poverty Dynamics in Indonesia (1993 - 2007). https://doi.org/10.13140/2.1.4043.5209

Wong, S. Y. (2012). Understanding Poverty: Comparing Basic Needs Approach and Capability Approach. SSRN, (May).

Yamin, S., \& Dartanto, T. (2016). Pengentasan Orang Miskin di Indonesia: Peran Modal Sosial yang Terlupakan. Jurnal Ekonomi Dan Pembangunan Indonesia, 17(1), 88-102. https://doi.org/10.21002/jepi.v17i1.656

Yusrina, A. (2013). Apakah Perempuan Kepala Rumah Tangga Lebih Miskin Daripada Laki-Laki Kepala Rumah Tangga? SMERU, pp. 11-17. 